\title{
KONDISI PEKERJA ANAK YANG BEKERJA DI SEKTOR BERBAHAYA
}

Oleh:

Eka Maulia Agustine, Ishartono, \& Risna Resnawaty

Email:

ekamaulia93@gmail.com; kesosish@gmail.com; happytruz@yahoo.com

\begin{abstract}
Abstrak
Anak selayaknya dilindungi serta diperhatikan hak-haknya. Negara dalam hal ini sudah sewajarnya menjamin dan melindungi hak-hak anak, baik dalam aspek sosial, politik, budaya dan ekonomi karena hal tersebut sudah diatur dalan Undang-undang. Pada kenyataannya, negara dan keluarga belum mampu menjamin terpenuhinya hak-hak anak. Permasalahan yang menjadi sorotan adalah banyaknya pekerja anak yang bekerja di sektor berbahaya. Keluarga yang mengandalkan mereka untuk bekerja agar dapat memberikan kontribusi berupa materi kepada keluarga atau bahkan untuk biaya mereka bersekolah. Dan hal tersebut tidak hanya melanggar hak-hak anak namun juga memberikan dampak yang buruk atau negatif bagi anak sebagai calon generasi penerus bangsa. Jaminan masa depan anak akan menjadi taruhannya jika kondisi tersebut terus berlangsung di masa yang akan datang, anak yang seharusnya mendapatkan pendidikan yang layak dan sesuai dengan apa yang seharusnya didapatkannya, seolah diputus untuk kepentingan ekonomi keluarga. Pekerja anak memang tidak sepenuhnya salah, namun ada batasan-batasannya, tidak seharusnya anak mendapatkan pekerjaan yang berat seperti memikul batu karena hal tersebut akan mempengaruhi perkembangan fisiknya, sehingga menghambat tumbuh kembang pekerja anak tersebut.
\end{abstract}

Kata kunci: anak, pekerja anak, hak anak

\section{Pendahuluan}

Kemiskinan merupakan masalah yang tidak pernah dapat terselesaikan di Indonesia. Kemiskinan merupakan hal yang kompleks karena menyangkut berbagai macam aspek seperti hak untuk terpenuhinya pangan, kesehatan, pendidikan, pekerjaan, dan sebagainya. Dari kemiskinan inilah salah satu faktor pendorong yang menyebabkan adanya pekerja anak. Tuntutan ekonomi membuat sebagian anak yang hidup dengan ekonomi lemah menjadikan anak dikeluarga tersebut ikut andil dalam mencari penghasilan keluarga. Jika berbicara mengenai fenomena pekerja anak, maka Hak Asasi Manusi (HAM) yang paling banyak disorot terutama untuk hak anak. Hal ini telah menjadi perdebatan di masyarakat luas baik di Indonesia dan di seluruh Negara-negara dunia.

Sebagaimana dilansir diatas dapat dipahami bahwa anak juga memiliki hak sebagaimana haknya orang dewasa, fakta ini yang kurang diperhatikan oleh masyarakat bahkan pemerintah selaku pemegang kekuasaan dalam sebuah negera. Yang lebih menyedihkan bagi masa depan anak adalah kurangnya kesadaran para orang tua akan masa depan anak mereka.

Di Negara kita, dapat dilihat dengan mudah menjumpai pekerja anak baik itu sebagai pengemis, tukang semir sepatu, dan lain-lainnya di tempat umum seperti jalan raya. Masih banyak yang tidak terlihat jelas, upaya-upaya pengeksploitasian anak-anak Indonesia. Mereka dieksploitasi sebagai pekerja kasar konstruksi dan tambang tradisional, penyelam mutiara, dan bahkan menjadi pekerja seks komersial anak. Anak adalah karunia Tuhan yang seharusnya dijaga dan dipenuhi hakhaknya sebagai manusia. 
Dalam konvensi Hak Anak, slah satunya anak harus mendapatkan haknya sebagai anak. Hak anak merupakan kebutuhan dasar anak yang harus dijamin, dilindungi dan dipenuhi oleh pemerintah, keluarga dan masyarakat.1

Indonesia merupakan salah satu Negara yang meratifikasi Konvensi Perserikatan BangsaBangsa (PBB) tentang hak-hak anak, melalui Keputusan Presiden (Keppres) no. 36/0 tanggal 25 Agustus 1990. Dengan adanya konvensi tersebut, berarti secara hukum Negara berkewajiban menjamin dan melindungi hak anak-anak, baik sosial, politik, budaya, dan ekonomi.

Di Indonesiapun telah ada aturan tentang hak anak. Pada kenyataannya, negara masih belum mampu memenuhi kewajibannya untuk melindungi hak-hak anak. Keberadaan pekerja anak merupakan salah satu contoh wajah belum terpenuhinya hak-hak anak. Dengan bekerja anak akan mempunyai tanggung jawab yang lebih jika dibandingkan dengan anak yang tidak bekerja.

Ketika anak-anak tidak mempunyai kesempatan untuk bersekolah, maka pilihan hidupnya hanya dua, yaitu: masuk angkatan kerja atau tidak. Akan tetapi perlu diingat bahwa anak-anak justru putus sekolah lantaran bekerja. Bahkan, di lingkungan yang kondusif untuk bekerja, konsekuensi yang muncul adalah gejala putus sekolah yang sering diawali dengan menggabungkan sekolah sambil bekerja. Tjandraningsih (1995). Orang tua yang mempunyai anak yang masih dalam usia sekolah namun tidak memiliki biaya yang mencukupi anaknya untuk bersekolah yang dikarenakan ekonomi yang lemah. Sebaiknya memahami terlebih dahulu dampak dari memperkerjakan anak-anak mereka. Patut digaris bawahi bahwa anak sudah sepatutnya dipenuhi hak-hak agar tidak mempengaruhi mereka di masa yang akan datang.

Orangtua hendaknya merawat dan membesarkan anak dengan sebaik-baiknya. Langkah yang paling utama adalah orangtua menyekolahkan anak tersebut. Dimana anak-anak dapat belajar dengan semestinya dan bermain atau bersosialisasi dengan teman-temannya. Tak jarang orangtua yang memaksa anaknya untuk bekerja, hal tersebut terindikasi sebagai tindakan pengeksploitasian

Mengeksploitasi anak dengan cara memperkerjakan anak Eksploitasi anak menunjuk pada sikap diskrimatif atau perlakuan sewenang-wenang terhadap anak yang dilakukan oleh keluarga ataupun masyarakat. Memaksa anak untuk melakukan sesuatu demi kepentingan ekonomi, sosial, ataupun politik tanpa memperhatikan hak-hak anak untuk mendapatkan perlindungan sesuai dengan perkembangan fisik, psikis \& status sosialnya (Suharto, 2005). Melibatkan anak-anak dalam dunia kerja mungkin bukan menjadi suatu masalah apabila mengukuti aturan hukum yang berlaku, serta keterjaminan terpenuhinya hak anak. Memang ini menjadi pekerjaan yang besar bagi seluruh stakeholder untuk merancang kebijakan pengentasan hak anak.

Dalam artikel yang dipublikasikan oleh tempo dikemukankan bahwa Komisi Nasional Perlindungan Anak (Komnas PA) mencatat, dari 6,5 juta pekerja anak berusia 6-18 tahun, sebanyak 26 persen di antaranya bekerja di lingkungan yang berbahaya bagi anak. Karena itu, 1,7 juta anak tersebut harus diprioritaskan untuk ditarik dari tempat mereka bekerja di lingkungan mereka bekerja, lalu disekolahkan kembali. Mereka bekerja di jalanan, di pabrik yang berurusan dengan bahan kimia, prostitusi, bahkan bekerja di sector domestic sebagai pembantu rumah tangga. Komisi Perlindungan Anak Indonesia (KPAI) terdapat sekitar 60 persen dari pekerja anak-anak menjadi pembantu. Tapi mereka tidak tercatat karena mereka diperkerjakan secara informasi. (http://www.tempo.co/read/news/2012/06/04/173408068/17-Juta-Anak-Bekerja-di-LingkunganBerbahaya, diakses tanggal 10 Desember 2014, pukul 22:31)

Dari data tersebut menjadi sebuah hal yang mencengangkan bagaimana tidak pekerja anak di Indonesia jumlahnya cukup fantastis, bahkan lebih dari satu perempatnya bekerja di sektor berbahaya dengan resiko yang lebih besar. Jumlah ini akan bertambah mengingat masih banyaknya anak yang bekerja disektor informal. Orang tua memang tidak seharusnya membebankan anak untuk bekerja.

\footnotetext{
${ }^{1}$ Konvensi Hak Anak pasal 6
} 
Anak seharusnya dibiarkan berkembang sesuai dengan tugas perkembangannya dan menikmati masa kecilnya.

Anak adalah gambaran dan cerminan masa depan, aset keluarga, agama, bangsa, negara. Dan anak juga merupakan generasi penerus di masa yang kan datang. Yang harus dijamin pemenuhan kebutuhannya. Mereka berhak untuk mendapatkan kebebasan, menikmati dunianya, dilindungi hakhak mereka tanpa adanya pengabaian yang dilakukan oleh pihak tertentu yang ingin memanfaatkan kesempatan untuk mencari keuntungaan pribadi.

\section{Kondisi Pekerja Anak yang Bekerja di Sektor Berbahaya}

Batasan mengenai siapa yang disebut anak berbeda disetiap Negara. Menurut The Minimum Age Convention nomor 138 (1973), pengertian tentang anak adalah seorang yang berusia 15 tahun ke bawah. Sedangkan dalam Convention In The Right Of The Child (1989) yang telah diratifikasi pemerintah melalui keputusan presiden (Keppres) nomor 39 tahun 1990 disebutkan bahwa anak adalah mereka yang berusia 18 tahun ke bawah. Sementara itu, UNICEF mendefinisikan anak sebagai penduduk yang berusia antara 0 sama ampai dengan 18 tahun.

Dari beberapa pengertian anak maka dapat disimpulkan bahwa, anak adalah mereka yang berusia 0-15 tahun kebawah. Adapun pada masa ini anak akan berada pada masa belajar dan membutuhkan waktu yang lebih banyak untuk bersosialisasi dengan teman sebayanya. Hal ini akan menjadikan anak dapat menjalani masa perkembangannya sesuai dengan yang sehrusnya. Namun ada pula anak yang memutuskan untuk bekerja demi membantu perekonomian keluarganya.

Pekerja anak adalah anak-anak yang melakukan pekerjaan secara rutin untuk orang tuanya atau untuk orang lain yang membutuhkan sejumlah besar waktu, dengan menerima imbalan atau tidak (Tjandraningsih, 1995). Menurut Manurung (1998), Pekerja anak adalah mereka yang berusia 10-14 tahun dan sedang bekerja paling sedikit satu jam secara kontinyu dalam seminggu. Merujuk pada pengertian pekerja anak yang telah dituliskan sebelumnya, maka dapat disimpulkan bahwa pekerja anak adalah tenaga kerja yang belum memasuki angkatan kerja, dan dipekerjakan dalam waktu yang panjang.

Pekerja anak seringkali tidak menyadari bahwa diri nya telah di eksploitasi. eksploitasi anak adalah memanfaatkan anak secara tidak etis demi kebaikan ataupun keuntungan orang tua maupun orang lain yang memanfaatkan jasanya. Menurut Karundeng (2005) terdapat beberapa jenis eksploitasi anak diantaranya adalah :
a. Perdagangan Manusia (Trafficking in Person)
b. Perbudakan (Slavery)
c. Prostitusi Anak (Child Prostitution)
d. Buruh Anak/Pekerja Anak (Child Labour)
e. Anak Jalanan (Children Of The Street)

Eksploitasi pada anak terjadi karena kurangnya perlindungan terhadap mereka, padahal secara fisik pekerja anak tidak berdaya jika dibandingkan dengan pekerja dewasa, maka anak tidak dapat melawan. Diperparah lagi dengan kondisi keluarga pekerja anak yang memiliki kondisi ekonomi lemah, dan menjadikan anak tersebut akan tunduk kepada perusahaan yang menampung pekerja anak. Hal ini dikarenakan pekerja anak membutuhkan pekerjaan untuk meningkatkan penghasilan keluargannya.

Jika kita berbicara tentang ekploitasi maka secara tidak langsung juga melanggar hak anak. Hak anak merupakan hak asasi manujsia, oleh karena itu hak anak wajib dipenuhi dan dilindungi oleh Negara maupun masyarakat. Menurut Konvensi Hak Anak (KHA) menegaskan bahwa secara garis besar ada empat hak anak, yaitu: 1. Hak terhadap kelangsungan hidup ( survival rights); 2, hak terhadap perliundungan (protection rights) 3. Hak untuk tumbuh kembang (development rights); 4 , hak untuk berpartisipasi (participation rights). Untuk lebih jelasnya hak-hak dasar anak adalah sebagai berikut: 
a. Hak untuk hidup yaitu memperoleh akses dan pelayanan kesehatan dan menikmati standar hidup yang layak seperti makanan yang cukup, air bersih dan tempat tinggal yang aman. Anak juga berhak memperoleh nama dan kewarganegaraan.

b. Hak untuk tumbuh dan berkembang yaitu memperoleh kesempatan untuk mengembangkan potensial semaksimal mungkin. Anak juga berhak memperoleh pendidikan yang memadai, diberi kesempatan bermain, berekreasi dan beristirahat.

c. Hak berpartisipasi yaitu hak untuk kesempatan menyuarakan pandangan dan ide-idenya, terutama persoalan yang berkaitan dengan anak.

d. Hak anak untuk memperoleh perlindungan yaitu hak anak yang harus dipenuhi untuk melindungi dirinya dari:

1. Eksploitasi ekonomi dan seksual

2. Kekerasan baik fisik maupun psikologi

3. Segala bentuk diskriminasi

Sebagaimana yang telah disebutkan sebelumnya dapat dipahami bahwa anak juga memiliki hak sebagaimana haknya orang dewasa, fakta ini yang kurang diperhatikan oleh masyarakat bahkan pemerintah selaku pemegang kekuasaan dalam sebuah negera. Yang lebih menyedihkan bagi masa depan anak adalah kurangnya kesadaran para orang tua akan masa depan anak mereka.

Pemenuhan hak anak pada pekerja anak seperti yang banyak diperbincangkan dalam realisasinya memang lemah. Contohnya seperti, pekerja anak yang mengabdikan separuh waktunya untuk bekerja secara otomatis pendidikannya akan sedikit terabaikan, waktu sepulang sekolah dihabiskan untuk bekerja, lebih parahnya lagi ada kasus pekerja anak putus sekolah karena lebih nyaman untuk bekerja. Belum lagi dalam urusan bersosialisasi dengan teman sebayanya, menghabiskan masa kecilnya dengan bermain bersama teman-teman dilingkungannya. Kondisi inilah yang dikhwatirkan akan mempengauhi masa depan pekerja anak tersebut.

Indonesia, melalui UU No.1 Tahun 2000, telah meratifikasi Konvensi ILO No. 182 mengenai Pelarangan dan Tindakan Segera Penghapusan Bentuk-bentuk Pekerjaan Terburuk untuk Anak (BPTA). Konvensi yang ditetapkan secara aklamasi pada tahun 1999 ini memberikan rincian tentang BPTA di mana anak di bawah 18 tahun tidak boleh terlibat di dalamnya. Konvensi juga menuntut Negara agar mengambil langkah-langkah segera dan efektif untuk memastikan ditetapkannya pelarangan dan penghapusan bentuk-bentuk terburuk pekerjaan terburuk untuk anak.

Dalam konvensi dan undang-undang tersebut di atas, istilah "bentuk-bentuk pekerjaan terburuk untuk anak" mengandung pengertian:

a. Segala bentuk perbudakan atau praktek sejenis perbudakan seperti penjualan dan perdagangan anak, kerja ijon (debt bondage), dan perhambaan (serfdom) serta kerja paksa atau wajib kerja, termasuk pengerahan anak secara paksa atau wajib untuk dimanfaatkan dalam konflik bersenjata;

b. Pemanfaatan, penyediaan, penawaran anak untuk pelacuran, produksi pornografi, dan pertunjukan-pertunjukan porno.

c. Pemanfaatan, penyediaan atau penawaran anak untuk kegiatan terlarang, khususnya untuk produksi dan perdagangan obat-obatan sebagaimana diatur dalam pernjanjian internasional yang relevan;

d. Pekerjaan yang sifat atau keadaan tempat pekerjaan itu dilakukan dapat membahayakan.2

Pekerjaan yang terburuk bagi anak merujuk pada pekerjaan yang berbahaya bagi anak dan memiliki resiko tinggi jika dibandingkan pekerjaan selain yang dicantumkan sebelumnya. Hal ini

\footnotetext{
${ }^{2}$ Hastadewi, Yuli. Dkk. 2004. Kondisi dan Situasi Pekerja Anak pada Beberapa Sektor di Tulungagung dan Probolinggo, Jawa Timur. UNICEF
} 
menjadi kekhawatiran bahwa resiko yang tinggi akan memperburuk kondisi anak yang bekerja di sector berbahaya.

Selanjutnya Pasal 74 UU No. 13 Tahun 2003 tentang Ketenagakerjaan menjelaskan bahwa siapapun dilarang mempekerjakan dan melibatkan anak pada pekerjaan-pekerjaan terburuk tersebut di atas, dan pelanggarannya dapat dikenai sanksi pidana.

Disadari atau tidak di Indonesia ini terdapat banyak peraturan yang mengatur tentang perlindungan terhadap anak, namun ketersesuaian antara pemenuhan dan peraturan dianggap masih kurang. Hal ini tidak serta merta dapat meniadakan pekerja anak. Di Negara kita ini masih ada yang beranggapan bahwa bekerja membantu orangtua adalah cerminan dari bakti terhadap orangtua. Dengan anggapan tersebut "oknum" memanfaatkannya untuk dapat mengeksploitasi anak.

Pekerja anak tidak akan menyadari bahwa dirinya telah di eksploitasi. Pekerja anak memang rentan terjadinya eksploitasi. Perusahaan tempatnya bekerja akan dengan mudah mengeksploitasi pekerja anak, tertutama apabila anak bekerja di sector berbahaya. Berikut adalah 19 jenis pekerjaan terburuk atau berbahaya bagi anak menurut JARAK (jaringan kerja LSM untuk penanggulangan pekerja anak) mengidentifikasi (memorandum-penghapusan bentuk-bentuk pekerjaan terburuk bagi anak di Indonesia, JARAK, 14 Juli 2001), yakni:

1. Anak-anak yang dilacurkan;

2. Anak yang diperdagang kan;

3. Anak yang bekerja di jermal;

4. Anak yang bekerja di pertambangangan (intan,batu bara, marmer, pasir);

3. Anak yang menjadi pembantu rumah tangga;

4. Anak yang menjadi tukabg pikul dan kuli pelabuhan;

5. Anak yang bekerja di sarana perhubungan (sebagaitukang becak, sais andong, kernet, dan lain-lain;

6. Anak yang bekerja pada pukat

7. Anak yang bekerja di perkayuan;

8. Anak yang bekerja menjadi pedagang asongan;

9. Anak bekerja menjadi penyelam mutiara;

10. Anak yang bekerja sebagai pemecah batu;

11. Anak yang bekara di daerah konflik;

12. Anak yang bekerja sebagai pemulung;

13. Anak yang bekerja sebagai nelayan;

14. Anak yang bekerja sebagai pembuat alas kaki;

15. Anak yang terlibat dalam perdagangan narkoba;

16. Anak yang bekerja di sektor formal;

Acuan yang digunakan untuk menetapkan sector-sektor terburuk kerja terburuk bagi anak meliputi jam kerja yang panjang (4-20 jam sehari), gaji yang dibawah standar, dan adanya risiko serta bahaya pekerejaan yang mengancam proses tumbuh kembang anak (misalnya: kecelakaan yang menyebabkan cacat fisik, kematian, keracunan, dan dampak terhadap tubuh yang baru diketahui setelah jangka waktu tertentu).

Resiko dan panjangnya jam kerja kadang tidak sebanding dengan upah yang diterima anak. Motivasi menambah penghasilan keluarga menjadi salah satu alasan bahwa pekerja anak masih mempertahankan pekerjaannya. Untuk menyelesaikan masalah tersebut diperlukan peran pekerja sosial. Adapun perannya adalah sebagai berikut:

1. Educator: memberikan pemahaman terhadap orangtua dan perusahaan yang mempekerjakan anak tentang dampak yang akan dirasakan oleh anak apabila perkerja anak baik itu di sektor berbahaya atau tidak.

2. Advocator: memberikan pendampingan terhadap pekerja anak

3. Konselor: membimbing klien untuk mengatsi masalahnya. 


\section{Penutup}

Hak Asasi Manusia (HAM) telah mengatur setiap perlindungan terhadap anak, begitu halnya dengan hak anak. Jaminan untuk mendapatkan perlindungan yang sesuai dengan nilai-nilai kemanusiaan dan agama, jaminan hak asasi tersebut juga diatur dan sesuai dengan nilai-nilai Pancasila dan tujuan negara sebagaimana tercantum dalam pembukaan UUD 1945. Ini menjadi sebuah keprihatinan manakala Negara belum bisa sepenuhnya menjamin keberlangsungannya, hal ini dapat dibuktikan dengan masih banyaknya pekerja anak. Pada dasarnya semua pekerjaan dalam memperoleh upah memiliki resiko masing-masing.

Merujuk kepada beberapa penelitian bahwa anak yang bekerja cenderung mengalami perubahan pada psikis dan fisiknya. Pekerja anak menjadi lebih dewasa sebelum pada waktunya. Menjadi sebuah keprihatinan bagaimana anak tersebut menghadapi masa depannya. Terbelenggunya anak dengan pekerjaan yang dijalaninya membuat anak melupakan pendidikannya.

Waktu yang mereka habiskan untuk bekerja adalah waktu mereka untuk mengenyam pendidikan dan bermain. Karena bekerja akan menghambat mereka untuk memperoleh pendidikan yang di butuhkan oleh seusianya sehingga memperoleh pekerjaan yang layak ketika mereka sudah siap bekerja. Ketertinggalan membuat mereka terkurung dalam kondisi seperti ini. Hadirnya pekerja anak memang tidak seharusnya disalahkan.

Dengan kondisi yang seperti ini tidak bisa dibiarkan situasinya terus berlarut perlu adanya pengentasan. Perlu ditangani secara serius, sehingga di masa yang akan datang kita tidak lagi mendengar adanya pekerja anak. Masalah pekerja anak masih menjadi dilematis namun tetap dilakukan upaya pencegahan dan harus mendapat perhatian serius bagi semua pihak, baik oleh pemerintah ataupun masyarakatnya sendiri. Agar situasi tersebut berlanjut atau bahkan menjadi lebih parah dibutuhkan penanganan yang serius dari pemerintah beserta seluruh stakeholder terkait. Memang tidak mudah untuk mengurangi atau bahkan meniadakan pekerja anak terutama di sektor yang berbahaya, karena hal tersebut menyangkut masalah kemiskinan terutama di Indonesia yang masih sangat tinggi. Seiring berkurangnya angka kemiskinan bisa dipastikan pekerja anak juga akan berkurang jumlahnya. Terlepas dari hal tersebut pekerja anak harus dijamin hak-haknya, dengan cara bekerja sama dengan perusahaan atau kelompok yang menaungi pekerja anak tersebut untuk lebih menjaga keselamatan dan tumbuh kembang anak tersebut agar tidak berpengaruh terhadap apa yang terjadi di masa yang akan dating

\section{Referensi:}

Hastadewi, Yuli. Dkk. 2004. Kondisi dan Situasi Pekerja Anak pada Beberapa Sektor di Tulungagung dan Probolinggo, Jawa Timur. UNICEF

Huraerah, Abumsi. Child Abuse (Kekerasan terhadap Anak). Bandung: Nuansa

Hurlock,Elisabeth, B. 2006. Psikologi perkembangan. Jakarta: Erlangga

Mallon,p, Gerald. Dkk. 2012. Modul Latihan Pekerja Sosial yang Berpusat pada Anak dan Keluarga:

Perlindungan Anak dan Rencana Permanensi, Jakarta: Save the Children

Rahman, Astriani. Eksploitasi Orang Tua Terhadap Anak Dengan Mempekerjakan Sebagai Buruh.

Jakarta. Universitas Guna Darma

Slamet, juli soemirat. 2007. Kesehatan Lingkungan. Yogyakarta: gadjah mada university press

Sulastri, dkk. 2007. Pekerja anak, Pendidikan anak pekerja\Buruh, Skema Bantuan, dan Komite

Sekolah (Pandangan Serikat Pekerja/Buruh), Jakarta. KBSI (konfederasi Serikat Buruh

Sejatera Indonesia), KSPI (Konfederasi Serikat Pekerja Seluruh Indonesia), KSPI

(Konfederasi Serikat Pekerja Indonesia)

Suyanto, Bagong. 2003. Masalah Sosial Anak. Jakarta: Kencana Prenada Media Group

\section{Referensi Lain:}


http://www.tempo.co/read/news/2012/06/04/173408068/17-Juta-Anak-Bekerja-di-LingkunganBerbahaya diakses tanggal 10 Desember 2014, pukul 22:31 